International Journal of Economics, Business and Accounting Research (IJEBAR)

Peer Reviewed - International Journal

Vol-4, Issue-2, 2020 (IJEBAR)

E-ISSN: 2614-1280 P-ISSN 2622-4771

https://jurnal.stie-aas.ac.id/index.php/IJEBAR

\title{
FACTORS THAT INFLUENCE SMES' PERCEPTIONS ABOUT THE IMPORTANCE OF PREPARING FINANCIAL STATEMENTS (CASE STUDY AT A BICYCLE SHOP IN SURAKARTA AND SUKOHARJO)
}

\author{
Rukmini1 LMS Kristiyanti2 M.Fachri Naufal Barokah3 \\ Institut Teknologi Bisnis AAS Indonesia \\ Email:rukmini.stie.aas@gmail.com \\ Lms.kristiyanti@yahoo.co.id \\ mfachrinaufalb@gmail.com
}

\begin{abstract}
Various problems that are still faced by Micro, Small and Medium Enterprises (MSMB) are in utilizing the use of financial statements. The inability to practice accounting is the main factor that causes problems and triggers MSMB failure in developing their business. This study aims to determine: (1) the effect of business size on MSMB perception on the importance of financial statement preparation, (2) the effect of time on MSMB perception on the importance of financial reporting, (3) the influence of educational background on MSMB's perception of the importance of preparing financial statements, (4) the effect of business size, length of business, educational background on MSMB's perception on the importance of preparing financial statements. The results of this study indicate that (1) there is no positive effect on the scale of the company on the use of accounting information. Evidenced by a regression coefficient the value of $t$ is smaller than $t$ table (2) there is a positive influence of accounting knowledge on the use of accounting information. Evidenced by a regression coefficient the value of $t$ is greater than $t$ table (3)) there is a positive influence on MSMB owner's perception of accounting from the use of accounting information. Evidenced by a regression coefficient the value of $t$ is greater than t table (4) there is a positive influence on the perception of SME owners about accounting, accounting knowledge, and company scale on the use of accounting information. Evidenced by the $\mathrm{F}$ value greater than $\mathrm{F}$ table.
\end{abstract}

Keywords: $\quad$ Effect of business size, length of business, educational background on perception, the importance of preparing financial statements.

\section{Introduction}

A few years ago, the population increased greatly from the number of available jobs. This specifically addresses young people to create their own opportunities by launching businesses. Most of them are classified as micro, small and medium enterprises (MSMEs) business sectors. Data from the Ministry of Cooperatives and Small and Medium Enterprises in 2014, there were around 57.8 million SMEs in Indonesia. In 2017 and the next few years, the number predicted by MSMEs will continue to grow.

So far, MSMEs have contributed 57-60\% of Gross Domestic Product (PBD) and employment rates are around $97 \%$ of all national workforce (MSME Business Profile by the LPPI and BI in 2015). Not much different from the notes of Kadin (Indonesian Chamber of Commerce), the contribution of the MSME sector to gross domestic product increased by $57.84 \%$ to $60.34 \%$ in the last five years. Employment absorption in this sector also rose from $96.99 \%$ to $97.22 \%$ in the same period. MSMEs also proved to be disapproved of the crisis. When the crisis hit in the period 1997-1998, only MSMEs were able to stand firm. Data from the Central Statistics Agency, after the economic crisis of 1997-1998, the number of MSMEs did not decrease, 
International Journal of Economics, Business and Accounting Research (IJEBAR)

Peer Reviewed - International Journal

Vol-4, Issue-2, 2020 (IJEBAR)

E-ISSN: 2614-1280 P-ISSN 2622-4771

https://jurnal.stie-aas.ac.id/index.php/IJEBAR

instead, it continued to increase, even being able to absorb 85 million to 107 million workers until 2012. In that year, the number of employers in Indonesia was 56,539,560 units. Of these, Micro, Small and Medium Enterprises (MSMEs) amounted to 56,534,592 units or $99.99 \%$. The rest, around $0.01 \%$ or 4,968 units is big business. From 2011 to 2012 there was growth in MSMEs and a decline in large businesses. If in 2011, the big business reached $41.95 \%$ the following year only $40.92 \%$, down around $1.03 \%$. In MSMEs the opposite is true. If Medium Enterprises in 2011 only 13.46\%, in 2012 it reached $13.59 \%$. There was an increase of $0.13 \%$. In contrast to small businesses, there was a slight decline from 2011. In that year it reached $9.94 \%$ but in 2012 it only reached $9.68 \%$, meaning an increase of around $0.26 \%$.

Indonesia has a diverse business sector and Micro, Small and Medium Enterprises is one of the pillars of business operations in this country. But until now, there are still many parties who need a business that makes financial statements are unnecessary and just a waste of time and money. In addition, the financial statements are still considered not to provide benefits that are proportional to the time and costs to be sacrificed. Regarding business people, they only use intuition and habit in making decisions on certain events. Thus, business actors will usually be confused about cash management, as well as cash value and distribution. In addition, business approvals do not have financial statements, Financial management is important to apply to MSMEs. According to Ediraras (2010), the MSME business which is managed financially and informed transparently and accurately will have a positive impact on the MSME business itself. Positive impact on the MSME business. The positive impact of financial management, which is a key factor in the success of MSMEs and can be used to maintain the sustainability of their businesses.

Business Size of Size is a number that indicates the size of a unit of measure or an object. Efforts made by humans to get money or goods needed to meet their daily needs and achieve prosperity in life. So according to my measurements, business is the size of the place of business that can be seen from the conversation. The law requires companies classified as MSMEs as small companies that are owned and managed by a person or owned by a small group of people with a certain amount of wealth and income. The age of the company (long business) is a company that stands, develops and survives. The age of the company is calculated from the time the company was established based on a deed of the establishment until the research was conducted. The results of tests conducted by Trisnawati (1998) and Beatty (1989) in Gumanti (2000) state that the company has long been established, choosing that it has gained a lot of experience. The longer the company, the more information obtained by the public about the company. And this will lead to consumer confidence in the company's products.

Education is a conscious effort carried out systematically in realizing teaching and learning so that students can develop their potential. With education, a person can have intelligence, noble character, personality, spiritual strength, and skills that are useful for oneself and society. In English, the word education is called education Where the etymological word comes from the Latin, namely Eductum. The wordEductum consists of two words, E which means development from inside out, and Ducoyang means developing. The meaning of education is the process of developing individual abilities and strengths.

\section{Research Method}

In this study, quantitative analysis is used. The population in this study is the Bicycle Shop located in Surakarta and Sukoharjo, Central Java. Based on the total number of studies above, 55 employees were obtained, so in the Isaac-Michael table column, $\mathrm{N}$ was chosen as large as 50 so rounding was done.

Quantitative analysis is used, namely data analysis by means of data consisting of numbers collected, analyzed (by calculation or research) as well as a comparison between one data with another. In order to answer the problem formulation in this study, the authors will conduct Data analysis by identifying financial reports that have been made by MSMEs and analyze how to approve MSMEs against approving financial reporting. 
International Journal of Economics, Business and Accounting Research (IJEBAR)

Peer Reviewed - International Journal

Vol-4, Issue-2, 2020 (IJEBAR)

E-ISSN: 2614-1280 P-ISSN 2622-4771

https://jurnal.stie-aas.ac.id/index.php/IJEBAR

Validity is a measure that indicates the level of validity or error of an instrument. A valid instrument has high validity. More, less valid instruments. A validity test is useful to know whether to approve what is requested must be approved because it is considered irrelevant.

The questionnaire instruments made must meet the validity and reliability, as well as the validation process carried out by the method of expert judgment or expert opinion. Testing the validity of the instruments in this study used research. Moment of Pearson. The Product Moment decision formula from Pearson, namely:

$r_{x y}=\frac{N \Sigma X Y-(\Sigma X)(\Sigma Y)}{\sqrt{\left.\left\{N \Sigma X^{2}-(\Sigma X)^{2}\right\} N \Sigma Y^{2}-(\Sigma Y)^{2}\right\}}}$

Information:

$r_{x y}=$ reflection coefficient between $\mathrm{X}$ and $\mathrm{Y}$

$\mathrm{X}=$ item score

$\mathrm{Y}=$ total score

$\mathrm{N}=$ number of respondents

$\Sigma X^{2}=$ the number of squares of the $X$ value

$\Sigma Y^{2}=$ the number of squares of the $\mathrm{Y}$ value

Item criteria declared valid if $\mathrm{r}$ count $>\mathrm{r}$ table. The criterion item is declared invalid if $\mathrm{r}$ count $\leq \mathrm{r}$ table for $\mathrm{n}=35$ is 0.334 , so $\mathrm{r}$ count $>\mathrm{r}$ table $>0.344$.

Item criteria declared valid if $r$ count $>r$ table. The item criterion is declared invalid if $r$ count $\leq \mathrm{r}$ table for $\mathrm{n}=35$ is 0.334 , so $\mathrm{r}$ count $>\mathrm{r}$ table $>0.344$.

\section{Reliability Test}

Support refers to the level of reliability of something. Reliable, can it be trusted to be used as a data collection tool because the instrument is good, cannot be tendentious, can be trusted, the data is indeed in accordance with reality so that even if taken several times the same.

The reliability test is useful for managing whether it can be used more than once, with the same respondent producing the resulting data. Instrument reliability characterizes the level of consistency. The reliability test is carried out on a trial data instrument that has claimed validity, where valid items are valid and their reliability is valid, while invalid statement items are rejected. The reliability test in this study tested the Alpha Cronbach experiment (Sugiyono, 2014: 365). The following is a formula for calculating instrument reliability:

$r_{11}=\left(\frac{k}{k-1}\right)\left(1-\frac{\Sigma \sigma b^{2}}{\sigma^{2} t}\right)$

Information:

$r_{11}=$ instrument reliability

$k \quad=$ number of questions or number of questions

$\Sigma \sigma b^{2}=$ number of item variations

$\sigma^{2} t=$ total variant 
International Journal of Economics, Business and Accounting Research (IJEBAR)

Peer Reviewed - International Journal

Vol-4, Issue-2, 2020 (IJEBAR)

E-ISSN: 2614-1280 P-ISSN 2622-4771

https://jurnal.stie-aas.ac.id/index.php/IJEBAR

The alpha test results or the reliability coefficient can be determined reliably if the alpha value> 0.05 and the category is based on Sugiyono's index reliability criteria quoted by Rahmasari (2015: 73) are:

Between 0.800 and 1.00: very high

Between 0.600 and 0.799: high

Between 0.400 and 0.599: enough

Less than 0.200: very low

\section{Multiple Regression}

This study was determined by looking at the level of data error of 5\%. The criterion for a $5 \%$ error level is rejected $\mathrm{r}$ count $>\mathrm{r}$ table, then $\mathrm{H}$ is rejected and $\mathrm{H}$ is accepted, conversely if $\mathrm{r}$ count $<\mathrm{r}$ table, $\mathrm{H}$ is accepted and $\mathrm{H}$ is rejected. The coefficient issued is stated to be significant if the value of $\mathrm{p}<0.05$.

Hypothesis III testing uses multiple regression analysis. Criteria for the error level of 5\%, price freedom Fcount> Ftable, then $\mathrm{H}$ is rejected and $\mathrm{H}$ is accepted. The multiple regression coefficients are recognized as significant if the $\mathrm{p}$-value $<0.05$. Double counting and $\mathrm{F}$ are done using SPSS Version 21.0 program. Contribution Model

$\mathrm{Y}=\mathrm{bo}+\mathrm{b} 1 \mathrm{X} 1+\mathrm{b} 2 \mathrm{X} 2+\mathrm{b}_{3} \mathrm{X}_{3}$

Keterangan:

$\mathrm{Y}=$ Perception of UMKM the importance of preparing financial statements

$\mathrm{X} 1=$ Business size

$\mathrm{X} 2$ = Length of effort

$\mathrm{X}_{3}=$ educational background

bo, b1, b2 and b3 = multiple regression coefficients.

\section{Hypothesis Test}

After data processing, data analysis with descriptive analysis and the results of statistical analysis are performed which provide a statistical interpretation of the results of each data processing, each statistical test, which is presented in a table with the help of IBM SPSS version 21.0. The data analysis techniques used are:

\section{Hypothesis Test (Statistical test t)}

The t-test statistic on planning shows the great influence of one independent variable or individual explanation in explaining the agreed variables.

Inggris

After analyzing the data and estimating the calculation results, the next step is to compare the estimated $t$ (significant) with a significance level of $0.5(5 \%)$ and the value of the table. To draw conclusions whether hypotheses 1,2, 3 are accepted or rejected using the following conditions:

Significance of $\mathrm{t}<0.05$, the alternative hypothesis is accepted.

Significance of $t>0.05$ then the significance of zero is accepted and the alternative hypothesis is rejected. Ho is there is no effect of the independent variable on the dependent variable and $\mathrm{Ha}$ is there is the effect of the independent variable on the dependent variable. 
International Journal of Economics, Business and Accounting Research (IJEBAR)

Peer Reviewed - International Journal

Vol-4, Issue-2, 2020 (IJEBAR)

E-ISSN: 2614-1280 P-ISSN 2622-4771

https://jurnal.stie-aas.ac.id/index.php/IJEBAR

$t=\frac{\bar{x}-\mu_{0}}{S / \sqrt{n}}$

Statistical test

Keterangan:

$\bar{x} \quad=$ rata-rata

$\mu_{0} \quad=$ nilai yang dihipotesiskan

$s \quad=$ standar deviasi / simpananan baku

$n \quad$ = banyak sampel

\section{Significance Test Simulation (Statistical Test F)}

The simultaneous significance test ( $F$ statistical test) on determining shows all the independent or independent variables entered in the model are supported together against the dependent / success variable.

$F=\frac{R^{2}}{\left(1-R^{2}\right)(n-K-1)}$

Where:

F: Approval of the probability distribution

$\mathrm{R}^{2}$ : Co-regression regression

$\mathrm{K}$ : The number of independent variables

$\mathrm{n}$ : Amount of data (sample)

After analyzing the data, and then considering the calculations, the next step will discuss the significance of F smaller or equal to 0.05 or sig F greater than 0.05 . Significance level F $<0.05$ and Fcount $>$ $\mathrm{F}$ table then the null hypothesis (Ho) is rejected and the alternative hypothesis (Ha) is accepted. Meanwhile if $\mathrm{F}>0.05$ and $\mathrm{F}$ count $<\mathrm{F}$ table then the null hypothesis (Ho) is accepted and the alternative hypothesis (Ha) rejected. Ho is there is no effect of the independent variable on the dependent variable and Ha is there is an effect of the independent variable on the dependent variable.

\section{Test the Coefficient of Determination $\left(\mathbf{R}^{2}\right)$}

The coefficient of determination $\left(\mathrm{R}^{2}\right)$ essentially measures the ability of the ability of the regression model to explain the dependent variables, Ghozali (2011: 97).

$\mathrm{R}^{2}=\frac{I K T}{J K T}$

JKR and JKT will not be negative, so their valuable value is zero. While the maximum value of a portion is one. Then it can be written $0 \leq \mathrm{R}^{2} \leq 1$ (Budiyono, 2009: 258-259).

\section{Results and Discussion}


International Journal of Economics, Business and Accounting Research (IJEBAR)

Peer Reviewed - International Journal

Vol-4, Issue-2, 2020 (IJEBAR)

E-ISSN: 2614-1280 P-ISSN 2622-4771

https://jurnal.stie-aas.ac.id/index.php/IJEBAR

\section{Results}

This study was determined by looking at the level of data error of 5\%. The criterion for a $5 \%$ error level is rejected $\mathrm{r}$ count $>\mathrm{r}$ table, then $\mathrm{H}$ is rejected and $\mathrm{H}$ is accepted, conversely if $\mathrm{r}$ count $<\mathrm{r}$ table, $\mathrm{H}$ is accepted and $\mathrm{H}$ is rejected. The coefficient issued is stated to be significant if the value of $\mathrm{p}<0.05$. Hypothesis III testing uses multiple regression analysis. The criterion for a $5 \%$ error level is agreed upon by Fcount $>$ Ftable, then $\mathrm{H}$ is rejected and $\mathrm{H}$ is accepted. The multiple regression coefficients are recognized as significant if the $\mathrm{p}$-value $<0.05$. Double counting and $\mathrm{F}$ are done using SPSS Version 21.0 program. Below will be discussed the results of multiple regression analyses.

Table 1 Results of Multiple Regression Analysis

\begin{tabular}{lllll}
\hline Sub Variable & $\begin{array}{l}\text { Coefficient } \\
\text { Regresi (b) }\end{array}$ & t-hcount & Sig. & Conclusion \\
& 0,222 & 1,258 & 0,105 & Not significant \\
Business size & 0,188 & 4,629 & 0,000 & Significant \\
Business age & 0,453 & 5.521 & 0,000 & Significant \\
Educational background & & & & \\
Constant $=6,976$ & & & & \\
R2 $=0,466$ & & & & \\
F count $=44.947$ & & & & \\
F table $=2,67$ & & & & \\
Sig. $=0,000$ & & & & \\
Sig. Business size 0,210 / $=0,105$ & & & &
\end{tabular}

From the results of the regression analysis it can be seen that multiple regression is as follows:

$\mathrm{Y}=\mathrm{K}+\mathrm{a} 1 \mathrm{X} 1+\mathrm{a} 2 \mathrm{X} 2+\mathrm{a} 3 \mathrm{X} 3$

$\mathrm{Y}=6,976+0,222 \mathrm{X} 1+0,188 \mathrm{X} 2+0,453 \mathrm{X} 3$

\section{Hypothesis Testing Results}

\section{Hypothesis Test (t statistical test)}

The t-test statistic on planning shows the great influence of one independent variable or individual explanation in explaining the agreed variables.

To read the coefficient of the line can be seen in column $t$ with significance. The regression line coefficient testing is carried out as follows:

For the business size variable (X1), the coefficient value 0.222 is found so the regression line equation is $\mathrm{Y}=6.976+0.222 \mathrm{X} 1$, with $\mathrm{t}$ arithmetic $=1.258, \mathrm{t}$ table $=1.976$, and sig. $=0.210$, because $\mathrm{t}$ arithmetic is smaller than $t$ table $(1.258<1.976)$ and the significance value is more than $0.05(0.210>0.05)$, then Ho can be accepted as a variable of business variables in accordance with the expectations of financial MSMEs.

For the business length variable (X2), the coefficient value is 0.188 so that the regression line equation is $\mathrm{Y}=6.976+0.188 \mathrm{X} 2$, with $\mathrm{t}$ arithmetic $=4.629, \mathrm{t}$ table $=1.976$, and sig. $=0,000$, because $\mathrm{t}$ arithmetic is greater than $t$ table (4.629> 1.976) and the significance value is less than $0.05(0.000<0.05)$, then Ho is rejected, which means a positive business length of MSME expectations regarding the use of accounting information .

For educational background variables (X3), the coefficient value is 0.453 , so the equation of the regression line is $\mathrm{Y}=6.976+0.453 \mathrm{X} 3$, with $\mathrm{t}$ arithmetic $=5.521, \mathrm{t}$ table $=1.976$, and sig. $=0,000$, because $\mathrm{t}$ arithmetic is greater than $\mathrm{t}$ table $(5.521>1.976)$ and the significance value is smaller than $0.05(0.00$ 
International Journal of Economics, Business and Accounting Research (IJEBAR)

Peer Reviewed - International Journal

Vol-4, Issue-2, 2020 (IJEBAR)

E-ISSN: 2614-1280 P-ISSN 2622-4771

https://jurnal.stie-aas.ac.id/index.php/IJEBAR

$<0.05$ ), then Ho is rejected, the variable change about accounting has a positive effect on the use of accounting information.

\section{Significance Test Simulation (Statistical Test F)}

Multiple regression analysis using the $\mathrm{F}$ (Fisher) test to examine the relationship between variables including business size, business duration, educational background on MSME perceptions about the matter of facilitating financial reporting on MSMEs in Surakarta and Sukoharjo. If the significance value is greater than 0.05 , the regression model is statistically significant. From the test results obtained the calculated F value of 44,947 is greater than the $F$ table of 2.67 with a significance of 0,000 . Because the value of $F$ count> F table (44.947> 2.67) and the significance is less than $0.05(0.000<0.05)$, it can be simplified hypothesis that states education towards MSME perceptions about the importance of financial reporting "is proven.

\section{Deteremination Coefficient (R2)}

The coefficient of determination is a tool to measure the effect of independent variables on variables. The coefficient of determination is large between 0 to 1 , the coefficient of determination of the number 1 , the greater the coefficient of the independent variable on the dependent variable. The R2 test results in this study obtained a value of 0.466 . This shows the perception of MSMEs about the importance of financial reporting on MSMEs in the cities of Surakarta and Sukoharjo influenced by variables of business size, length of business, and educational background of $46.6 \%$, while the remaining $53.4 \%$ depends on other factors not included in the study this.

\section{Discussion}

MSMEs regarding business size, length of business, and educational background towards MSME's perception of the importance of preparing financial reports. The discussion of each variable is presented as follows:

Effect of business size on MSME perceptions of the importance of making financial reports on bicycle shops in Surakarta and Sukoharjo regencies.

The results showed that the size of the business did not conflict with the perception of MSMEs about the importance of preparing financial statements. This is discussed with the results of statistical tests for scale variables obtained by a business calculation of 1.258 and t table 1.976 with a significance level of 0.210 , because $t$ arithmetic $<t$ table $(1.258<1.976)$, and a significance greater than $0.05(0.210>0,05)$, then this research succeeded in proving the first hypothesis, which reads "No positive effect on accounting information efforts".

The results showed that the size of businesses in the bicycle shop MSME in the cities of Surakarta and Sukoharjo were still relatively small, so the effect on using accounting information was very small. This shows that the hypothesis in this study was rejected, this means that the size of the business size does not affect the perception of MSME about the importance of preparing financial statements. This contradicts the theory of Linear Diah Sitoresmi and Fuad (2013) which states that companies that have advanced will require an additional number of workers by increasing company activity. Adding several businesses will also increase the income or sales obtained, the higher the company in using accounting is also the greater. According to Arizali Aufar (2013) the higher the scale of the business and the more complex business processes will increase the accounting needs for business continuity, likewise accounting information becomes useful as an effort to improve managerial results. 
International Journal of Economics, Business and Accounting Research (IJEBAR)

Peer Reviewed - International Journal

Vol-4, Issue-2, 2020 (IJEBAR)

E-ISSN: 2614-1280 P-ISSN 2622-4771

https://jurnal.stie-aas.ac.id/index.php/IJEBAR

Based on research conducted by Chelsy Wulandari and Dani Hidayat (2012) shows that business scale variables are not significant to the preparation and use of accounting information. Not related to the scale of the effort to prepare and use accounting information because measuring the scale of the effort in this study only uses the number of employees. Besides, research from Nita Andriani and Zuliyati (2015) shows that business scale variables do not significantly influence the use of accounting information. More and more companies that are approved by entrepreneurs do not need to use accounting information by managers or business owners of Troso ikat.

\section{The longstanding influence on MSME perceptions about the importance of preparing financial statements}

The results showed a positive influence on the company towards the perception of MSMEs about the importance of making financial reporting. This is evidenced by the results of statistical tests for the age variable of the company obtaining a calculated test value of 4.629 and t table 1.976 with a significance level of 0.008 because of $t$ arithmetic $>t$ table (4.629>1.976) with a significance level greater than $0.05(0.000$ $<0,05)$, then this study succeeded in proving the second hypothesis stating "Has a positive effect on the company on the perception of MSMEs about the importance of preparing financial statements".

The results showed that the age of the company determines a significant negative effect on MSME perceptions about the importance of preparing financial statements in small and medium businesses. This shows that the hypothesis in this study is accepted, it means the length of effort has a positive effect on MSME perceptions about the use of accounting information. The results of this study are similar to the results of the research of Holmes and Nicholls (1989) and Murniati (2002) which states the age of the company has a significant effect on the level of use of accounting information in small and medium businesses. However, this result is different from the results of Era Astuti's (2007) research which states that the company does not approve the level of preparation and use of accounting information.

According to Murniati (2002), the characteristics of company silk are very challenging to the company's growth, one of the characteristics is the old company. The company determines the company's experience in doing business, according to the need to use accounting information will also increase along with the increasing difficulty of the company.

The negative number of companies in this study shows more. This is considering a company that has just started or has more than 10 years of age, has more than 10 years, has more than 10 years, more than 10 years, more people want to know more both from within and from outside the company for the development and survival of the company.

The influence of owner education on the use of accounting information in small and medium businesses

The results of this study indicate the positive influence of educational background on the perception of MSMEs about the importance of preparing financial reports. This is evidenced by the results of the statistical test $t$ for MSME credit rating variables on accounting for the use of accounting information obtained a $\mathrm{t}$ value of 5.521 and $\mathrm{t}$ table 1.976 with a significance level of 0.000 , because of $\mathrm{t}$ arithmetic $>\mathrm{t}$ table $(5.521>1.976)$, and a greater significance of $0.05(0,000<0.05)$, this study succeeded in proving the hypothesis which states "Providing a positive influence on educational background on the perception of MSEs about the importance of preparing financial statements".

The results showed that manager education had a significant influence on MSME perceptions about the importance of preparing financial reports. Formal education issued by managers/owners of MSMEs is very challenging to the skills and abilities needed by managers/business owners in managing their businesses. The low level of formal education of the owner/manager will also lower the preparation and use of accounting information in its use compared to the owner/manager who has a higher level of formal 
International Journal of Economics, Business and Accounting Research (IJEBAR)

Peer Reviewed - International Journal

Vol-4, Issue-2, 2020 (IJEBAR)

E-ISSN: 2614-1280 P-ISSN 2622-4771

https://jurnal.stie-aas.ac.id/index.php/IJEBAR

education. Owners or managers of companies that have additional education will be asked for the preparation and use of accounting information, such as those obtained from the education and training that are followed to support the owner of knowledge related to accounting. Other factors that can influence accounting information Manager/owner educational benefits with differences in the level of formal education that is issued. Formal education that is approved by the owner/manager can add to the manager's confidence in doing so in using accounting information for decision making.

The results of this study reinforce the research of Holmes and Nicholls (1989) and Murniati (2002) which states that the level of education of managers/owners greatly influences the level of information used in small and medium businesses. A low level of formal education also prepares and uses accounting information compared to a higher level of formal education.

\section{Conclusions}

Based on the results of research and discussion, several conclusions can be drawn:

1. Not important. "MSMEs about the importance of financial planning. This is calculated from the calculated value smaller than $t$ table $(1.258<1.976)$ and the significance value greater than $0.05(0.210>$ $0.05)$.

2. It is a positive influence of long-standing efforts on MSME perceptions about the importance of financial reporting. This is evidenced by the calculated $t$ value greater than $t$ table $(4.629>1.976)$ and the significance value is less than $0.05(0.000<0.05)$.

3. The importance of background education about perceptions about MSMEs about the importance of financial reporting. This is evidenced by the calculated t value greater than $t$ table $(5.521>1.976)$ and a significance value of 0.000 , which means it is smaller than $0.05(0.000<0.05)$.

4. Periodically positive the size of the business, length of business, and educational background on the perception of MSMEs about the importance of preparing financial reports. This means that the calculated $\mathrm{F}$ value is greater than the $\mathrm{F}$ table $(44.947>2.67)$ and the significance value is smaller than $0.05(0.000<0.05$.

\section{References}

Abrory,2014.Faktor-Faktor yang mempengaruhi kebutuhan standar akuntansi keungan (SAK) bagi usaha kecil dan menengah (UKM) (Studi Kasus pada UKM Marmer / Onix Di Kabupaten Tulungagung)

Andriani, Lilya, Anantawikrama Tungga Atmadja dan Ni Kadek Sinarwati. 2014.Analisis penerapan pencatatan keuangan berbasis SAK ETAP pada usaha Mikro Kecil dan Menengah (UMKM) (Sebuah Studi Intrepetatif Pada Peggy Salon).

Anggrayni, L. (2014). Menelusuri Persepsi Pelaku Usaha UMKM atas Penggunaan Laporan Keuangan. Skripsi.Universitas Negeri Gorontolo.

Astiani,Yulia. (2017). Pengaruh persepsi pelaku usaha mikro kecil dan menengah tentang akuntansi, dan skala usaha terhadap penggunaan informasi akuntansi. Skripsi. Yogyakarta. Universitas Negeri Yogyakarta.

Baridwan, Zaki. 1992. Intermediate Accounting, Edisi7. Yogyakarta : Cetakan Pertama, BPFE.

BPS. 2006a. Analisis Profil Prusahaan/ Usaha provinsi Jawa Tengah Tahun 2006. Semarang : Salemba Empat

Diyana, Ita Yustian Free, 2017. Analisis pengelolaan keuangan usaha mikro kecil dan menengah (Studi Kasus Pada Asosiasi Batik Mukti Manunggal Kabuupaten Sleman). Skripsi. Yogyakarta; Universitas Sanata Dharma. 
International Journal of Economics, Business and Accounting Research (IJEBAR)

Peer Reviewed - International Journal

Vol-4, Issue-2, 2020 (IJEBAR)

E-ISSN: 2614-1280 P-ISSN 2622-4771

https://jurnal.stie-aas.ac.id/index.php/IJEBAR

Handayani, 2009, Analisis Perancangan dan Penerapan Akuntansi pada UKM Artagalantina

Ikatan Akuntan Indonesia. 2009.Standar Akuntansi Keuangan Entitas Tanpa Akuntabilitas Publik. Jakarta: Salemba Empat.

Khaidir, Mohammad, 2013, Persepsi para Pelaku UMKM (Usaha Kecil dan Menengah) Terhadap Penerapan Akuntans Di Desa Porame Kecamatan Kinovaro Kabupaten Sigi.

Krisnaditya, A. (2013). Persepsi Pelaku UMKM atas Tujuan Laporan Keuangan. Skripsi. Universitas Negeri Yogyakarta.

Kristian, C. (2010). Pengaruh Skala Usaha, Umur Perusahaan, Pendidikan Pemilik terhadap Penggunaan Informasi Akuntansi pada UMKM di Kabupaten Blora. Skripsi. Universitas Negeri Semarang

Mansyur, 2012, Persepsi Pelaku Usaha Mikro Kecil Menengah Atas Penggunaan Laporan Keuangan (Studi Empiris pada UMKM Mitra Binaan PT.Telkom Indonesia, Tbk Wilayah VII KTI).

Munawir, S., M., M., Akuntan. (2002). Akuntansi keuangan dan Manajemen. Yogyakarta: BPFE.

Putra, Hermon Adhy dan Elisabeth Penti Kurniawati. 2012. Penyusunan laporan keuangan untuk usaha kecil dan menengah (UKM) berbasis akuntansi keuangan entitas tanpa akuntabilitas public (SAK ETAP).

Reeve, J.M. dkk. (2011). Pengantar Akuntansi. Jakarta: Salemba Empat.

Soemarso. (2004). Akuntansi Suatu Pengantar. Jakarta: Salemba Empat.

Sugiyono. (2007). Statistika Untuk Penelitian. Jakarta: Alfabeta.

Sugiyono. (2010). Metode Penelitian Pendidikan. Bandung: Alfabeta.

Sugiyono. (2011). Metode Penelitan Kuantitatif, Kualitatif, dan R \& D. Bandung: Alfabeta.

Undang- Undang Republik Indonesia No 20 Tahun 2008 tentang Usaha Mikro, Kecil dan Menengah.

Sekaran, Uma, dan Bougie Roger. 2006. Research Methods for Business-A Skill BuildingApproach. USA: John Wiley \& sons, Inc.

Zahri, Mustafa Rifan. 2014. Faktor-faktor yang mempengerahui persepsi pengusaha tentang pentingnya pelaporan keuangan dengan Pjumlah kredit serta prospek implementasi SAK ETAP ( Studi Empiris pada UMKM di Kabupaten Boyolali ).

https://www.academia.edu/18287924/PROPOSAL_PENELITIAN_baru

file://C:/Users/ASUS/Downloads/Documents/132114119_full.pdf 